\title{
251. 画像処理フィルターの設計と評価
}

\author{
Estimate of tmage-Filter
}

\section{大分医科大学医学部附属病院 放射線部}

\author{
○船越 猛 \\ (Takeshi Funakoshi \\ 中山 晃一 \\ ( Kouichi Nakayama)
}

【目的】 空間周波数特性に優れるバ夕一ワースフィルターと、ウィナー型フィルターについて、使 用者側で決定しなければならないパラメー夕が幾つかあるが、その条件は未知である。

今回は、線状線源亡投影画像の 2 次元パワースペクトルからフィルターのパラメータを決定したので 報告する。

【条件】 Z Z C D I G I TRAC ORB I TER 75 シンチパック 7000

画像マトリクス $128 * 12820$ 秒 20 分収集心筋画像

【方法】 1. 心筋 S P E C T において、任意の投影データの 2 次元パワースペクトルを求め、こ れよりバターワースフィルターのカットオフ周波数を決定する。

2:ウィナー型フィルターの条件の一つ、F W H M 線状線源の L S F より求める。ウィナー型 フィルターのもう一つの条件であるスペクトル S N 比を、信号部 (心筋) と雑音部（肺野）にR O I を設定し (Fig. 1)、各々のパワースペクトルから求めた。また、同 R O I 内の計数值の統計值の 比 (分散比) む求めた。

【結果】1２２０秒，80秒，20分収集画像のパワースペクトル（v=0に於ける2 次元パワー スペクトルの断面）をFig. 4 に示す。これよりカットオフ值（D 0 ）を0.15 cycles/pixcelと した。 (1 9.2 2ピクセル) 次数は $\mathrm{N}=8$ とした。 フィルター㚾理前後の画像とパワースペク トルをFig. 2,3 に示す。

2.コリメータ表面から $0,10 ， 20 \mathrm{~cm}$ の F HMは 2.6，3.8，6! 0ピクセルであった。 S P E C T 時を考え、1 $5 \mathrm{~cm}$ に於ける FWHMを内挿して 5 ピクセルを求めた。 30 秒収集画像の $\mathrm{CM}=0.239$ (分散比)，0４８（パワースペクトル比）であった。処理前後の画像とパワー スペクトルをFig. 5，6に示す。

【考察】 1 . バターワースフィルターのカットオフ值は、個々の画像毎に 2 次元パワースペクト ルによって求めるのが良い。 また、その值の評価において吉 2 次元パワースペクトルは有効である。 2. ウィナー型フィルターのパラメータ C M (雑音対信号比) は統計值（分散）が一般に用いられ る、本来はパワースペクトルの比で表わされる。

2 次元パワースペクトルを求めることは、フィルターの設計（パラメータの決定）とその判定を行う うえで有効な方法である。

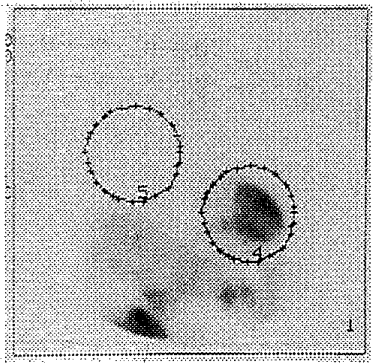

F i g. 1

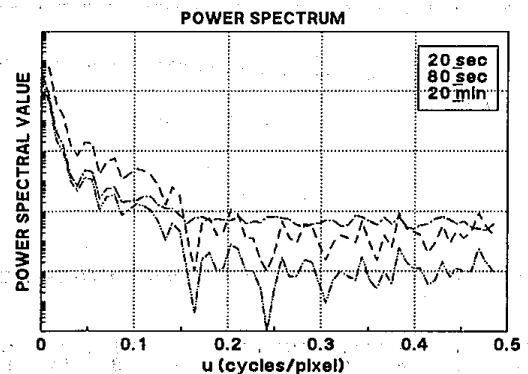

F i g . 4

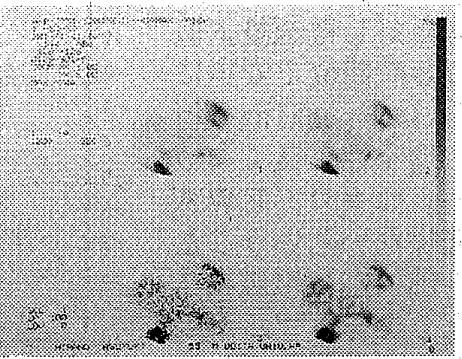

F i g. ' 2

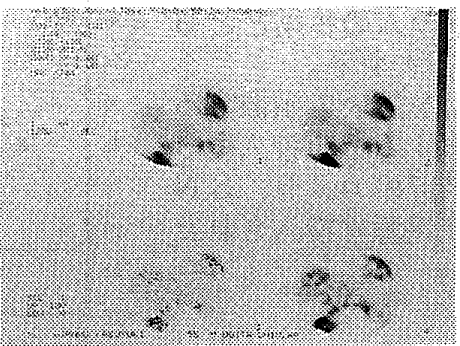

F i g. 5

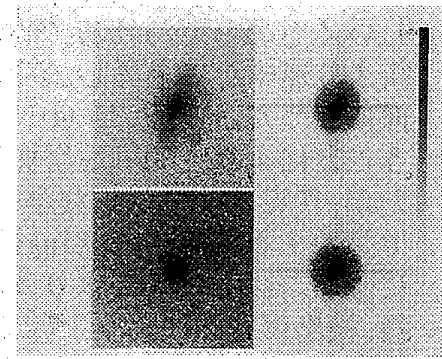

F i g. 3

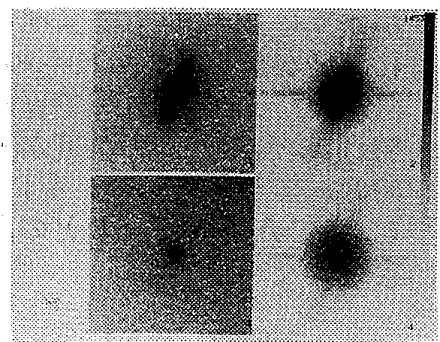

F i g. 6 